\title{
Characterization of Endogenous Gibberellins and Molecular Cloning of a Putative Gibberellin 3-Oxidase Gene in Bunching Onion
}

\author{
Nobutaka Shiraiwa \\ Tottori Horticultural Experiment Station, Kyuhin Sand Dune Sub-Station, Sakaiminato, Tottori \\ 684-0073, Japan
}

\author{
Kaori Kikuchi and Ichiro Honda \\ National Institute of Vegetable and Tea Science, Ano, Mie 514-2392, Japan \\ Masayoshi Shigyo \\ Faculty of Agriculture, Yamaguchi University, Yoshida, Yamaguchi 753-8511, Japan \\ Hiroko Yamazaki \\ National Agricultural Research Center for Tohoku Region, Morioka, Iwate 020-0123, Japan \\ Daisuke Tanaka, Kenji Tanabe, and Akihiro Itai ${ }^{1}$ \\ Faculty of Agriculture, Tottori University, Koyama, Tottori 680-8553, Japan
}

\begin{abstract}
AdDitional INDEX words. Allium fistulosum, bolting, chromosome 7A, active gibberellin, GA, 13-non-hydroxylation pathway

Abstract. To clarify the role of gibberellin (GA) in the growth of bunching onion (Allium fistulosum), identification of endogenous GAs and expression analysis of a putative gibberellin 3-oxidase $(A f G A 3$ ox 1$)$ were conducted. $\mathrm{GA}_{1}, \mathrm{GA}_{3}$, $\mathbf{G A}_{4}, \mathbf{G A}_{9}, \mathbf{G A}_{20}$, and $\mathrm{GA}_{34}$ were identified with levels of $\mathrm{GA}_{4}$ and $\mathrm{GA}_{9}$ being higher than those of $\mathrm{GA}_{1}, \mathbf{G A}_{3}$, and $\mathrm{GA}_{20}$. The young seedlings were clearly elongated by exogenous $\mathrm{GA}_{4}$ treatment but not by $\mathrm{GA}_{3}$. These results indicate that the 13-non-hydroxylation pathway of GA biosynthesis may be predominant in shoots with GA $_{4}$ playing an important role in the growth of bunching onion. Expression of $A f G A 30 x 1$ was higher in leaf sheaths than leaf blades during vegetative growth. In reproductive organs, expression of $A f G A 3 o x 1$ was higher at early and middle development stages in the stalks but was detected at a late development stage in the umbels. $A f G A 3 o x 1$ was mapped on chromosome 7A from shallot, a bunching onion-related species.
\end{abstract}

Bunching onion is an important leafy vegetable crop in East Asian countries such as Japan, China, and Korea (Inden and Asahira, 1990). Bunching onions are classified into two types on the basis of their edible parts, leaf and leaf sheath types.

At present, there are many cultivars and strains adapted to different regions with year-round cultivation being common in Japan. Bunching onion is biennial, usually vernalizing in winter and bolting early the next spring. Plants that have bolted lose their marketability because their flower stalks become too hard to eat. Requirements for bolting have been extensively studied under a number of environmental conditions in various varieties. For example, Yamasaki et al. (2000a, 2000b) investigated the effects of temperature and photoperiod during vernalization on flower initiation and revealed that a long-day photoperiod promoted flower development and elongation of the flower stalk after flower initiation.

Gibberellins are known to play important roles in a number of physiological processes during plant growth, one of the most characteristic of which is shoot elongation (Davies, 2004). It

Received for publication 13 July 2011. Accepted for publication 11 Oct. 2011. This work is supported in part by Grants-in-Aid from the Japanese Society for the Promotion Science (No. 19580042).

We thank Ms. S. Sanagawa and T. Araki (National Institute of Vegetable and Tea Science) for their technical assistance. We also thank Kyowa Hakko Co., Ltd., for donating $\mathrm{GA}_{4}$.

${ }^{1}$ Corresponding author. E-mail: itai@muses.tottori-u.ac.jp. was previously reported that GA-defective and non-responding plants show a dwarf phenotype (Hooley, 1994; Swain and Olszewski, 1996) and, moreover, that GAs play an important role in the bolting of some plants (Pharis and King, 1985). In addition, Zeevaart et al. (1993) reported that long-day conditions induced an increase in GAs and subsequent bolting in spinach (Spinacia oleracea). An increase in endogenous GAs was also reported during bolting after cold treatment in coldrequiring plants such as Raphanus sativus (Nishijima et al., 1998), cabbage (Brassica oleracea var. capitata) (Hamano et al., 2002), and tulip (Tulipia gesneriana) (Rebers et al., 1995). In Arabidopsis thaliana, cold treatment was also shown to induce an increase in GAs and bolting (Xu et al., 1997).

In the major GA biosynthetic pathway in higher plants, gibberellin 3-oxidase [GA 3-oxidase (electrical conductivity 1.14.11.15)] catalyzes the conversion of $\mathrm{GA}_{9}$ to $\mathrm{GA}_{4}$ and $\mathrm{GA}_{20}$ to $\mathrm{GA}_{1}$ (Hedden and Kamiya, 1997). Several GA-deficient dwarf mutants with reduced GA 3-oxidase activity have been isolated in pea (Pisum sativum) [le (Ingram et al., 1984)], rice (Oryza sativa) [dy (Kobayashi et al., 1989)], and A. thaliana [ga4 (Talon et al., 1990)]. The le mutant is rescued by $\mathrm{GA}_{1}$, but not by $\mathrm{GA}_{20}$, and shows low activity in $\mathrm{GA}_{20}$ to $\mathrm{GA}_{1}$ metabolism (Ingram et al., 1984). The gene encoding GA 3-oxidase has also been cloned from various plant species (Chìng et al., 1995, 1997; Itoh et al., 2001; Lester et al., 1997; Martin et al., 1997; Spielmeyer et al., 2004; Yamaguchi et al., 1998). 
GAs are considered to be essential for seed germination, leaf growth, inflorescence stem elongation, and seed development in bunching onion. Therefore, it is important to investigate the identification of the bioactive GAs and the molecular regulation of GA biosynthetic genes as a first step toward understanding the physiological role of GA in bunching onion. However, endogenous GAs in bunching onion have yet to be studied. In this report, we investigated endogenous GAs and

Table 1. Classification of flower developmental stages [according to Eguchi et al. (1958) and Yamasaki et al. (2000b)] used in the present study of bunching onion.

\begin{tabular}{ll}
\hline Code & \multicolumn{1}{c}{ Developmental stage } \\
\hline 0 & Vegetative \\
I & Apical dome enlarging to spathe formation \\
II & Floret formation \\
III & Perianth and stamen formation \\
IV & Anther and pistil formation \\
V & Pollen and ovule formation \\
VI & Pollen grain and early stage of stigma formation \\
VII & Flower opening \\
\hline
\end{tabular}

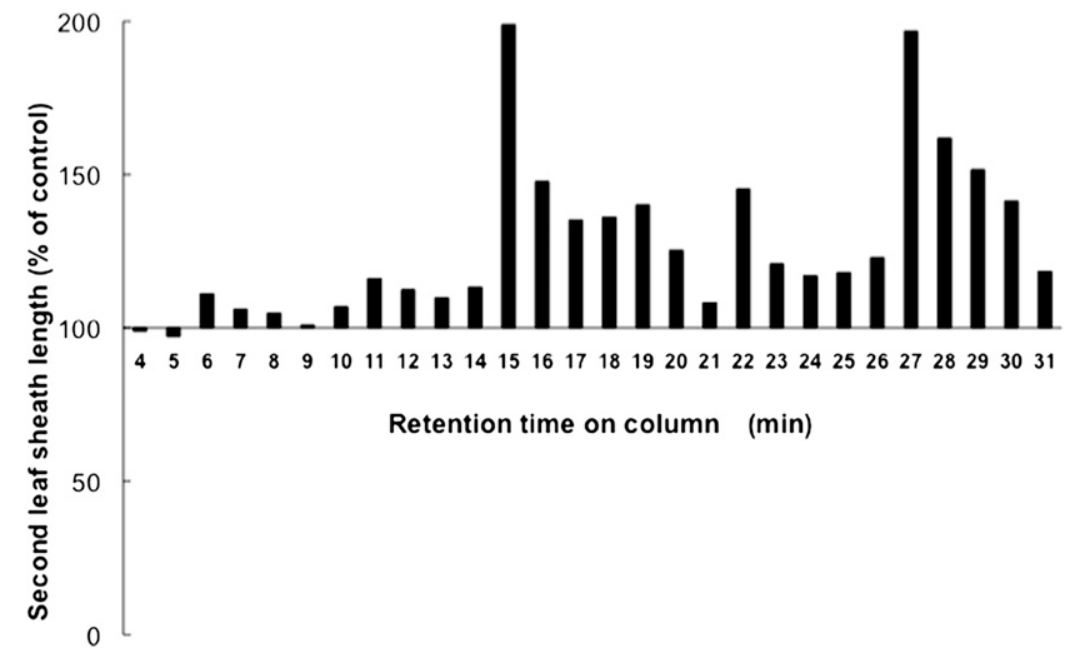

Fig. 1. Distribution of GA-like activity in extracts of bunching onion shoots fractionated by highperformance liquid chromatography. Each fraction was bioassayed using a modified rice microdrop assay with the dwarf rice 'Tanginbouzu'. Responses to $\mathrm{GA}_{3}: 50 \mathrm{pg} / \mathrm{plant}=143 \%$ of the control, 100 $\mathrm{pg} / \mathrm{plant}=171 \%$ of the control, and $300 \mathrm{pg} / \mathrm{plant}=200 \%$ of the control. $\mathrm{GA}=$ gibberellin .

Table 2. Gas chromatography-mass spectrometry identification of GAs in the shoots of bunching onion.

\begin{tabular}{lccc}
\hline $\begin{array}{l}\text { Identified } \\
\mathrm{GAs}\end{array}$ & $\begin{array}{c}\text { Retention } \\
\text { time }(\mathrm{min})\end{array}$ & $\mathrm{KRI}^{\mathrm{z}}$ & Principal ions and relative abundance (\% base peak $)^{\mathrm{y}}$ \\
\hline $\mathrm{GA}_{3}$ & 15 & 2692 & $504\left(\mathrm{M}^{+}, 100\right), 475(7.6), 387(6.0), 370(10.7), 208(19.4)$ \\
$\mathrm{GA}_{1}$ & 16 & 2670 & $506\left(\mathrm{M}^{+}, 100\right), 491(16.6), 448(11.2), 376(14.2), 207(5.2)$ \\
$\mathrm{GA}_{20}$ & $22-23$ & 2494 & $418\left(\mathrm{M}^{+}, 100\right), 404(10.5), 375(23.1), 359(12.0), 301(9.3)$ \\
$\mathrm{GA}_{34}$ & $25-26$ & 2667 & $506\left(\mathrm{M}^{+}, 100\right), 459(4.6), 431(4.7), 416(3.8), 372(7.3)$ \\
$\mathrm{GA}_{4}$ & 27 & 2515 & $418\left(\mathrm{M}^{+}, 40.6\right), 386(33.1), 328(26.3), 284(100), 225(58.6)$ \\
$\mathrm{GA}_{9}$ & 30 & 2327 & $330\left(\mathrm{M}^{+}, 6.0\right), 298(100), 286(18.4), 270(53.7), 243(30.7)$
\end{tabular}

${ }^{\mathrm{z}} \mathrm{KRI}=$ Kovats' retention indices (Kovats, 1958). KRI of authentic GAs: $\mathrm{GA}_{3}=2692, \mathrm{GA}_{1}=2668$, $\mathrm{GA}_{20}=2491, \mathrm{GA}_{34}=2665, \mathrm{GA}_{4}=2510, \mathrm{GA}_{9}=2326$.

${ }^{\mathrm{y}}$ Identified as methyl ester timethylsilyl ether derivatives by comparison with reference spectra and KRI data (Gaskin and MacMillan, 1991).

$\mathrm{GA}=$ gibberellin . analyzed the expression of a putative GA 3-oxidase in vegetative and reproductive tissues of bunching onion.

\section{Materials and Methods}

Qualitative analysis of gibBerellins. Bunching onion 'Cho-etsu' was cultivated in a field at the Tottori Horticulwas sown on 3 Oct. 2002 and transplanted on 28 Nov. Plants were harvested on 28 Mar. 2003. After removing the roots, plants were placed in a freezer and kept at $-20{ }^{\circ} \mathrm{C}$.

qualitative analysis of the GAs, five plants were mixed filtered through a Buchner funnel, and concentrated in vacuo methanol, passed through Bond Elut C18 and DEA (Varian, Palo Alto, CA) cartridges, and evaporated to dryness. The residue separated by high-performance liquid chromatography -D; $10 \mathrm{~mm}$ i.d. $\times 250-\mathrm{mm}$ column Sensho, Tokyo, Japan), eluted for 2 min with $30 \%$ aqueous methanol containing $1 \%$ acetic acid followed by a linear gradient to $100 \%$ methanol for $28 \mathrm{~min}$ and for $20 \mathrm{~min}$ with $100 \%$ methanol. Elution was run at a flow rate of $3 \mathrm{~mL} \cdot \mathrm{min}^{-1}$, the column was kept at 40 ${ }^{\circ} \mathrm{C}$, and fractions were collected every minute. The GA activity of aliquots of each separated fraction was examined using the rice microdrop method reported by Nishijima and Katsura (1989). Putative GA fractions were methylated by ethereal diazomethane, dried, trimethylsilylated with $N$-methyl- $N$ (trimethylsilyl)-trifluoroacetamide, and subjected to gas chromatography-mass spectrometry (GC/MS) analysis.

GC/MS analysis was carried out using a mass spectrometer (JMS-700; JEOL, Tokyo, Japan) with a gas chromatograph (6890N; Agilent Technology, Santa Clara, CA) fitted with a capillary column (DB-1, $0.25 \mathrm{~mm}$ i.d. $\times$ $15 \mathrm{~m}, 0.25-\mu \mathrm{m}$ film thickness; Agilent Technology). The carrier gas was helium at a flow rate of $1 \mathrm{~mL} \cdot \mathrm{min}^{-1}$, the injection port temperature was $250{ }^{\circ} \mathrm{C}$, and samples were introduced by splitless injection. The column oven temperature was programmed at $130{ }^{\circ} \mathrm{C}$ for $2 \mathrm{~min}$ before being elevated to $220{ }^{\circ} \mathrm{C}$ at $32{ }^{\circ} \mathrm{C} \cdot \mathrm{min}^{-1}$ and then $270{ }^{\circ} \mathrm{C}$ at $8{ }^{\circ} \mathrm{C} \cdot \mathrm{min}^{-1}$. In $\mathrm{GC} / \mathrm{MS}$ identification, mass spectra and the retention time on the $\mathrm{GC}$ of putative GAs were compared with those of authentic GAs and Kovats retention index (KRI) (Gaskin and MacMillan, 1991). Authentic GAs were obtained from L.N. Mander (Australian National University, Canberra, Australia). 


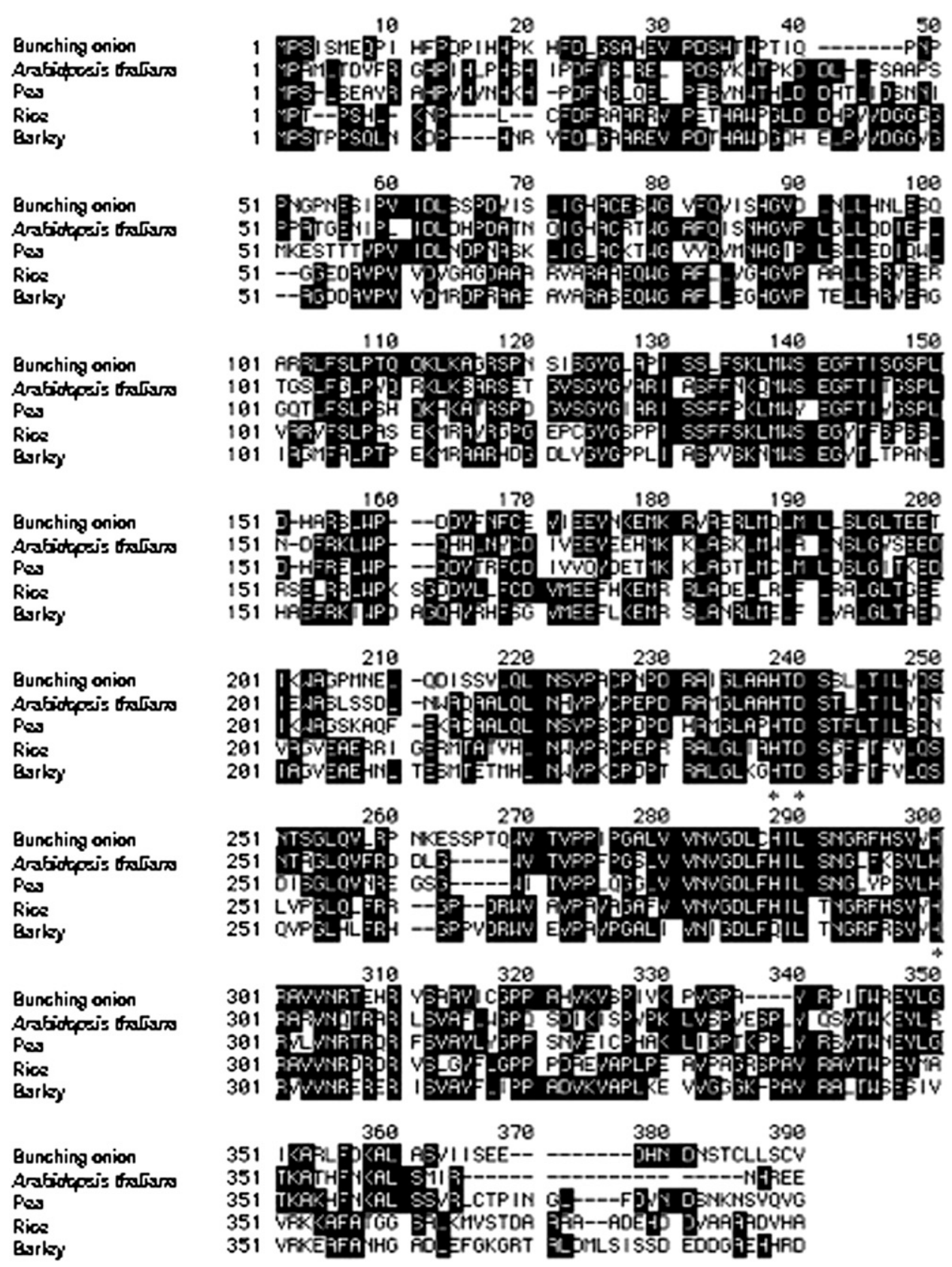

Fig. 2. Alignment of deduced amino acid sequences of AfGA3ox 1 and other GA 3-oxidases. Conserved regions are boxed in black. Asterisks indicate the putative $\mathrm{Fe}^{2+}$-binding motif at the active site of 2-oxoglutarate-dependent dioxygenases (Thomas et al., 1999). Alignment is shown for the deduced amino acid sequences of bunching onion AfGA3oxl (GenBank accession no. AB303422), Arabidopsis GA4 [At1g15550 (Chiang et al., 1995, 1997)], pea LE [AF001219 (Lester et al., 1997; Martin et al., 1997)], rice OsGA3ox2 [AB056519 (Itoh et al., 2001)], and barley HvGA3ox1 [AY551430 (Spielmeyer et al., 2004)]. GA = gibberellin.

estimated from peak area ratios between ${ }^{2} \mathrm{H}_{0}$ and ${ }^{2} \mathrm{H}_{6}$ molecular ions of each GA examined by GC/SIM.

GibBerellin treatment OF SEEDLINGS. 'Cho-etsu' was sown three seeds per hole on a 288-hole plug tray $(10 \mathrm{~mL} / \mathrm{plug}$; Landmark Plastics, Akron, OH) containing commercial soil mixture (Napra; Yanmer, Tokyo, Japan) and grown in a phototron $\left[20 / 15^{\circ} \mathrm{C}, 12 / 12 \mathrm{~h}\right.$ (light/ dark), $\left.158 \mu \mathrm{mol} \cdot \mathrm{m}^{-2} \cdot \mathrm{s}^{-1}\right]$. Ten $\mathrm{d}$ after sowing, $5 \mu \mathrm{g} \mathrm{GA}$ (Tokyo Kasei, Tokyo, Japan) and $\mathrm{GA}_{4}$ (Kyowa Hakko Co. Ltd., Tokyo, Japan) in $0.5 \%(\mathrm{v} / \mathrm{v})$ methanol were applied to each plug. Fourteen d after treatment, plant height was measured.

Molecular ClONing OF PUTATIVE GIBBERELLIN 3-OXIDASE CDNA (AFGA3ox1). Total RNA was isolated from shoots of "Choetsu' using the hot borate method described by Wan and Wilkins (1994). First-strand cDNA was synthesized from $1 \mu \mathrm{g}$ of total RNA using M-MLV reverse transcriptase (ReverTra Ace; Toyobo, Osaka, Japan). Partial cDNA fragments of GA 3-oxidase were amplified by reverse transcription polymerase chain reaction (PCR) using two degenerate primers; sense: 5' -ATGTGGYMNGARGGNTTYAC-3' and antisense: 5'-GTRTGNGCNGCNAGNCCCAT-3' $(\mathrm{Y}=\mathrm{C} / \mathrm{T}, \mathrm{M}=\mathrm{A} / \mathrm{C}, \mathrm{N}=\mathrm{A} / \mathrm{C} / \mathrm{G} / \mathrm{T}$, $\mathrm{R}=\mathrm{A} / \mathrm{G})$. Degenerate oligonucleotide primers were designed from conserved regions of $A$. thaliana GA4 (Chiang et al., 1995, 1997) and $G A 4 H$ (Yamaguchi et al., 1998), pea $L E$ (Lester et al., 1997; Martin et al., 1997), rice OsGA3ox 1 and OsGA3ox2 (Itoh et al., 2001), barley (Hordeum vulgare) Hv3oxl and Hv3ox2 (Spielmeyer et al., 2004), and other plant species. Amplified fragments (290 bp) were purified and cloned into a pGEM$\mathrm{T}$ easy vector (Promega, Madison,

Quantification of endogenous gibBerellins. 'Cho-etsu' was planted in 10-L plastic boxes on 11 Aug. 2003 and grown under natural conditions in a rain-shelter plastic house until 15 Oct. Plants were then moved to a phytotron $\left[25 / 15^{\circ} \mathrm{C}, 12 /\right.$ $12 \mathrm{~h}$ (light/dark), $158 \mu \mathrm{mol} \cdot \mathrm{m}^{-2} \cdot \mathrm{s}^{-1}$ ] for an additional $30 \mathrm{~d}$. After removal of the roots, plants were divided into leaf sheaths and leaf blades, placed in a freezer, and kept at $-80^{\circ} \mathrm{C}$. After $100 \mathrm{~g}$ of frozen materials were homogenized in liquid nitrogen, and then extracted with $80 \%$ methanol, deuterated GAs (obtained from L.N. Mander) were added to the extracts following the same purification procedure described previously. The GA levels were
WI). DNA sequencing was performed using a Big Dye terminator cycle sequencing kit (Applied Biosystems, Foster City, CA) and an ABI PRISM 3100 Avant Genetic Analyzer (Applied Biosystems) and analyzed using DNASIS pro software (Hitachi Software Engineering Co., Tokyo, Japan). Two antisense cDNA-specific oligonucleotide primers were designed at the $5^{\prime}$ end of cDNA for RACE PCR reactions. Full-length cDNA was obtained using $3^{\prime}$ and $5^{\prime}$ RACE methods with a GeneRacer Kit (Invitrogen, Carlsbad, CA) according to the manufacturer's instructions. The primary RACE primer was $5^{\prime}$-AATCATCTGGCCAAAGAGAG - $3^{\prime}$. 
The second RACE primer was 5'-CGTGCATGATCGAGAGGGGA-3'. The 5' RACE PCR products (500 bp) were gel-purified, subcloned into the pGEM-T easy vector, and sequenced.

Expression analysis of $\boldsymbol{A} \boldsymbol{F} \boldsymbol{G} \boldsymbol{A} 3 \boldsymbol{o x} 1$. Gene expression of $A f G A 3 o x 1$ was analyzed in vegetative tissues of bunching onion. 'Cho-etsu' was planted in 10-L plastic boxes on 15 Sept. 2005 and grown under natural conditions in a glasshouse until 26 Nov. Total RNA was then isolated from the roots, leaf sheaths, and leaf blades. For Northern blot analysis, $10 \mu \mathrm{g}$ of total RNA was fractionated on $1.2 \%$ agarose gel containing $0.66 \mathrm{M}$ formaldehyde and blotted onto Hybond $\mathrm{N}^{+}$nylon membranes (GE Healthcare, Little Chalfont, U.K.). Hybridization of the DNA blots was performed using a ${ }^{32} \mathrm{P}$-labeled $A f G A 3$ ox 1 full-length cDNA fragment. Post-hybridization washes were as follows: $2 \times 15$ $\min$ at $65^{\circ} \mathrm{C}$ in $0.2 \times \mathrm{SSC}(0.15 \mathrm{M} \mathrm{NaCl}$ and $0.015 \mathrm{M}$ sodium citrate, $\mathrm{pH} 7$ ) and $0.1 \%$ sodium dodecyl sulphate, after which the membranes were exposed to an imaging plate (Fuji Film, Tokyo, Japan). Signals were detected with an image analyzer (FLA5000; Fuji Film).

Gene expression analysis of $A f G A 3$ ox 1 at different reproductive stages was then conducted. Developmental flower stages and flower stalk length were scored according to Table 1 and sampled at each stage from Dec. 2004 until May 2005. After removal of the roots, leaf sheaths, and leaf blades, flower stalks from approximately five plants were divided into umbels and

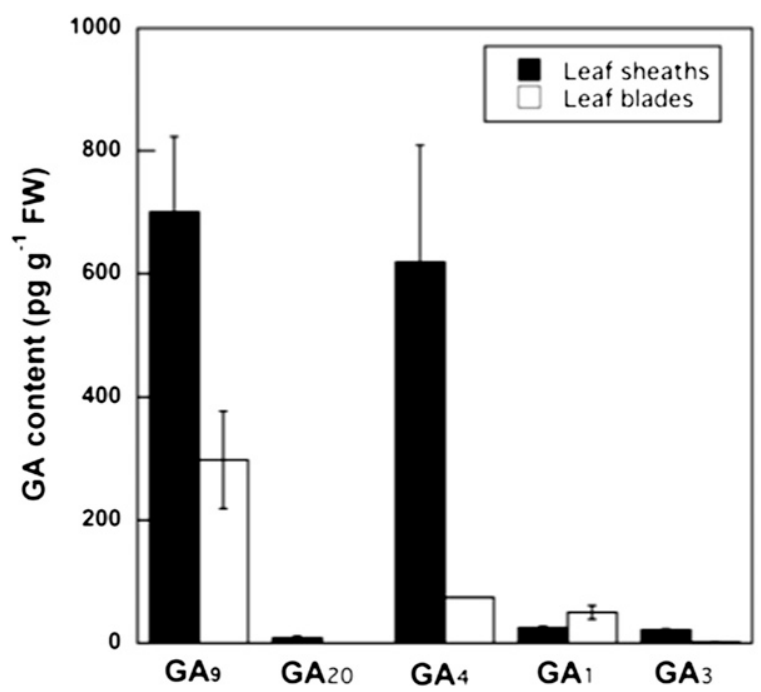

Fig. 3. The precursor $\left(\mathrm{GA}_{9}\right.$ and $\left.\mathrm{GA}_{20}\right)$ and active $\mathrm{GA}\left(\mathrm{GA}_{1}, \mathrm{GA}_{3}\right.$, and $\left.\mathrm{GA}_{4}\right)$ contents of bunching onion leaf sheaths and leaf blades $30 \mathrm{~d}$ after transplanting. Vertical bars indicate SD $(n=3) . G A=$ gibberellin.

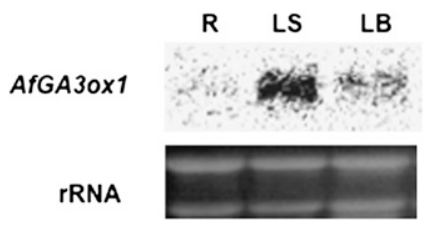

Fig. 4. Expression analysis of the $A f G A 3$ oxl gene in vegetative tissues of bunching onion. RNA was extracted from roots (R), leaf sheaths (LS), and leaf blades (LB) at $72 \mathrm{~d}$ after transplanting, and then $10 \mu \mathrm{g}$ of total RNA was loaded per lane and stained with ethidium bromide. stalks, placed in a freezer, and kept at $-80{ }^{\circ} \mathrm{C}$. Northern blot analysis was conducted as described previously.

Chromosomal location of $\boldsymbol{A} \boldsymbol{F} \boldsymbol{G} \boldsymbol{A} 30 x \boldsymbol{1}$ in shallot. A series of alien monosomic addition lines of bunching onion carrying single chromosomes of shallot (Allium cepa var. aggregatum; $2 \mathrm{n}=17, \mathrm{FF}+1 \mathrm{~A}$ to $\mathrm{FF}+8 \mathrm{~A}$ ) was used (Shigyo et al., 1996). PCR amplifications of genomic DNA of shallot and bunching onion were achieved using AfGA3oxl-specific primers; sense: 5' ATGCCTTCCATTTCAATGGAACAA-3' and antisense: 5' CTTCCCATTCATTCATTGGATGC-3' . Amplified fragments were digested with $R s a \mathrm{I}$, and the products were separated by electrophoresis in $2.0 \%$ agarose gel and then stained with ethidium bromide to identify the chromosomal location of the AfGA3oxl gene.

Statistical analysis. Data were subjected to one-way analysis of variance (ANOVA) according to treatment. All ANOVAs were performed with JMP statistical software (Version 6.0; SAS Institute, Cary, NC) using treatments as a statistical parameter at a significant level of $P<0.05$. Means were separated using Tukey's multiple range test.

\section{Results}

QuAlitative ANALYSis OF ENDOGENOUS GiBberellins. Extracts from the shoots of bunching onion were shown to contain several fractions with GA-like activity (Fig. 1). Endogenous gibberellins, $\mathrm{GA}_{1}, \mathrm{GA}_{3}, \mathrm{GA}_{4}, \mathrm{GA}_{9}, \mathrm{GA}_{20}$, and $\mathrm{GA}_{34}$, were detected by comparison of their mass spectra and KRI with those from a spectral library (Gaskin and MacMillan, 1991) (Table 2).
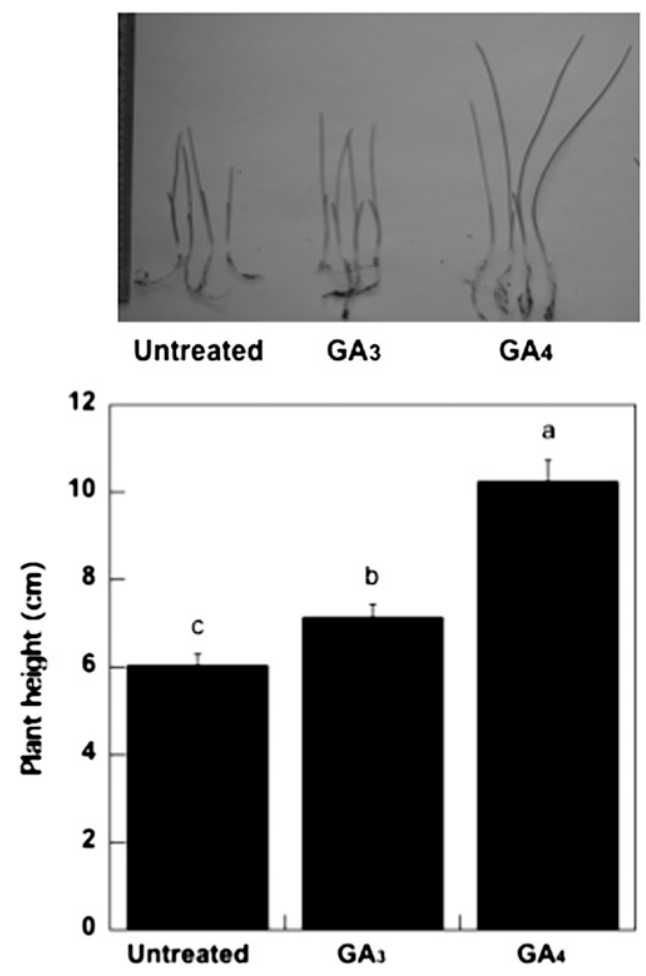

Fig. 5. Effects of $\mathrm{GA}_{3}$ and $\mathrm{GA}_{4}(5 \mu \mathrm{g}$ in $0.5 \%$ methanol) applied $10 \mathrm{~d}$ after sowing on plant height $14 \mathrm{~d}$ after treatment of bunching onion seedlings. Vertical bars indicate SD $(n=15)$. Values with different letters are significantly different by Tukey's multiple range test $(P<0.05)$. GA $=$ gibberellin. 
However, GAs were not identified in fractions 17 to 19 and 28 to 29 despite their higher GA-like activity.

Cloning of CDNA encoding gibBerellin 3-oxidase. The sequence of the PCR fragment (290 bp) had high homology with onion expressed sequence tag (EST) sequences (CF440541 and CF445692). We obtained a full-length cDNA using a combination of $3^{\prime}$ and 5' RACE and PCR based on the EST information. The resulting fragment was $1208 \mathrm{bp}$ and was named

(A)

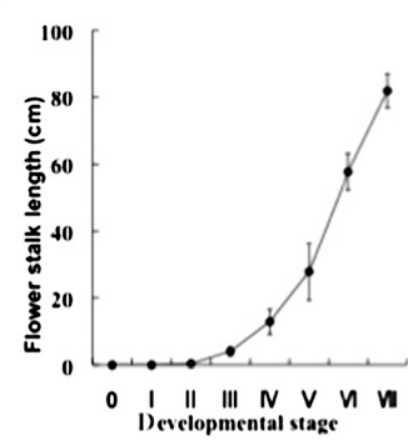

(C)

AfGA30x1

rRNA
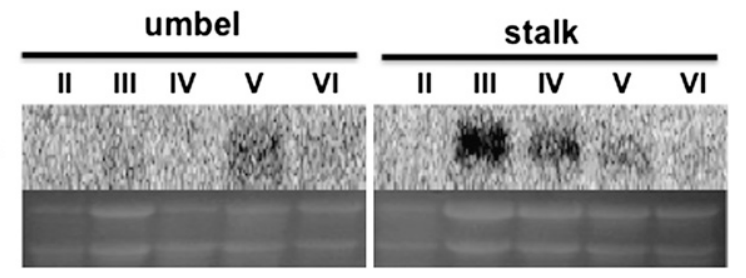

Fig. 6. Expression analysis of the $A f G A 3 o x 1$ gene during reproductive growth of bunching onion. (A) Relationship between flower developmental stage and stalk length (Table 1). Vertical bars indicate the SD $(n=10)$. (B) Flower stalks of bunching onion at different stages. After removal of roots, leaf blades, and leaf sheaths in reproductive growth and the flower stalk were divided into five developmental stages of the umbel and stalk; II: 0 to $3 \mathrm{~cm}$, III: 3 to $5 \mathrm{~cm}$, IV: 5 to $15 \mathrm{~cm}, \mathrm{~V}: 15$ to $40 \mathrm{~cm}$, VI: $40 \mathrm{~cm}$ or more, respectively. (C) Ten micrograms of total RNA was loaded per lane and stained with ethidium bromide. Northern blot analysis was performed using a ${ }^{32} \mathrm{P}$-labeled AfGA3ox 1 full-length cDNA fragment.

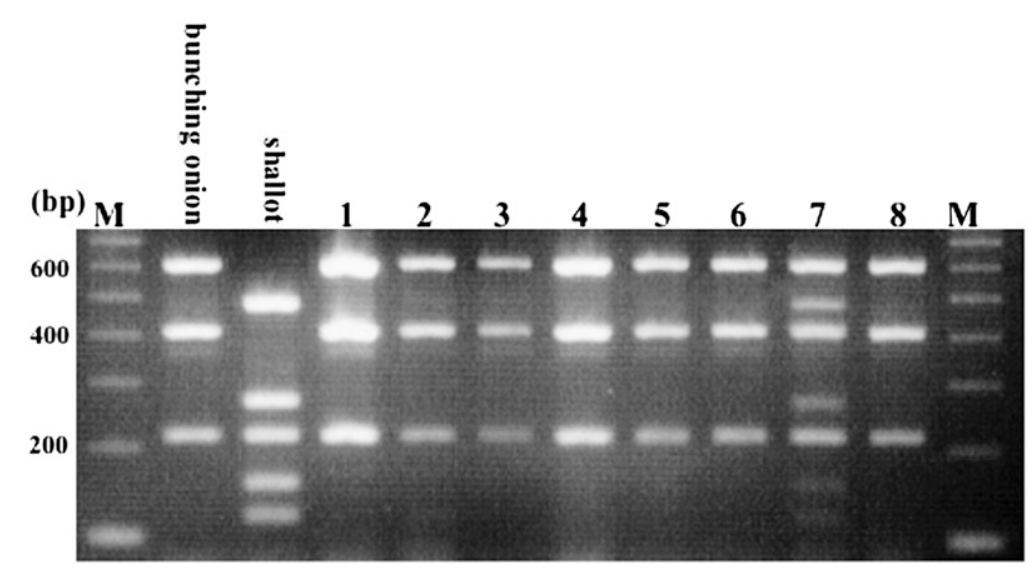

Fig. 7. Identification of the chromosomal location of the AfGA3oxl gene in shallot by PCR-RFLP analysis. Amplified fragments were digested with RsaI. Lanes 1 to 8: bunching onion plus shallot chromosomes $1 \mathrm{~A}$ to $8 \mathrm{~A}$, respectively (Shigyo et al., 1996). The first and last lanes contain 100-bp ladder markers. PCR = polymerase chain reaction; RFLP = restriction fragment length polymorphism.
AfGA3ox1. AfGA3ox1 contained an open reading frame consisting of 365 amino acids, and as shown in Figure 2, the deduced amino acid sequence shared high homology with other GA 3-oxidases as follows: $62 \%$ with $A$. thaliana $\mathrm{GA}_{4}, 53 \%$ with pea LE, 45\% with rice OsGA3ox1, and 43\% with barley Hv3ox1.

QuANTITATIVE ANALYSIS OF ENDOGENOUS GIBBERELLINS AND AF $\boldsymbol{G} \boldsymbol{A} 3$ ox 1 EXPRESSION ANALYSIS DURING VEGETATIVE GROWTH. In leaf sheaths and leaf blades, the $\mathrm{GA}_{9}$ content was higher than $\mathrm{GA}_{20}$; that of $\mathrm{GA}_{4}$ was higher than $\mathrm{GA}_{1}$ and $\mathrm{GA}_{3}$ (Fig. 3). Content of $\mathrm{GA}_{9}$ and $\mathrm{GA}_{4}$ in the leaf sheaths was higher than in the leaf blades. Expression of $A f G A 3 o x 1$ was high in leaf sheaths but low in leaf blades of bunching onion (Fig. 4). This was in accordance with the levels of $\mathrm{GA}_{4}$, which were higher in leaf sheaths than leaf blades (Fig. 2). The roots showed no expression of $A f G A 3 o x 1$. $\mathrm{GA}_{4}$ had a stronger promoting effect than $\mathrm{GA}_{3}$ on first leaf length in bunching onion (Fig. 5).

EXPRESSION OF THE $\boldsymbol{A F G A 3 O x} 1$ GENE DURING REPRODUCTIVE GROWTH. Flower stalks grew rapidly from flower developmental Stage II (Table 1; Fig. 6A). Expression of AfGA3ox1 was high at early to middle stages (length $3-15 \mathrm{~cm}$ ) in the stalks (Fig. 6B-C) and observed at flower developmental Stage V (length $15-40 \mathrm{~cm}$ ) in the umbels. These results indicate that expression of AfGA3ox 1 plays a role in stalk extension and the late stage of floret (umbel) development in bunching onion.

Chromosomal location of $\boldsymbol{A F G A 3 o x} 1$ in shallot. PCR gave same-sized bands of $\approx 1.23 \mathrm{~kb}$ (data not shown) in both shallot and bunching onion. In PCR-restriction fragment length polymorphism (RFLP) analysis, bands of $0.5,0.25,0.2$, 0.15 , and $0.13 \mathrm{~kb}$ were observed in shallot and $0.6,0.4$, and 0.23 $\mathrm{kb}$ in bunching onion. In addition, the $\mathrm{FF}+7 \mathrm{~A}$ line contained bands from both bunching onion (FF) and shallot (AA) (Fig. 7). This result indicates that the AfGA3oxl gene is located on chromosome 7 in shallot.

\section{Discussion}

Three C-13-hydroxylated GAs $\left(\mathrm{GA}_{1}, \mathrm{GA}_{3}\right.$, and $\left.\mathrm{GA}_{20}\right)$ and three C-13-non-hydroxylated GAs $\left(\mathrm{GA}_{4}, \mathrm{GA}_{9}\right.$, and $\left.\mathrm{GA}_{34}\right)$ were identified in bunching onion. These results indicate that both early 13-hydroxylation and non-hydroxylation pathways of GA biosynthesis (Yamaguchi, 2008) may operate in bunching onion. However, higher levels of non-13-hydroxylated GAs were detected in the leaf sheaths and leaf blades. A higher level of $\mathrm{GA}_{4}$ in leaf sheaths was in accordance with higher expression of AfGA3oxl in leaf sheaths. Moreover, exogenous $\mathrm{GA}_{4}$ had a stronger effect than $\mathrm{GA}_{3}$ on first leaf length in seedlings. This suggests that the 13-non-hydroxylation pathway of GA biosynthesis may be predominant with $\mathrm{GA}_{4}$ playing an important role in the growth of bunching onion. However, further studies on feedback regulation of GA biosynthetic and catabolism genes including GA 3-oxidase and GA 2-oxidase and are needed to clarify this hypothesis.

In onion (Allium cepa), $\mathrm{GA}_{1}, \mathrm{GA}_{4}, \mathrm{GA}_{8}$, $\mathrm{GA}_{9}, \mathrm{GA}_{12}, \mathrm{GA}_{15}, \mathrm{GA}_{20}, \mathrm{GA}_{24}, \mathrm{GA}_{34}, \mathrm{GA}_{44}$, $\mathrm{GA}_{51}$, and 3-epi-GA $\mathrm{G}_{4}$ have been identified in the leaf sheath of 7-month-old seedlings 
(Nojiri et al., 1993). Furthermore, in 4-week-old onion plants, the levels of $\mathrm{GA}_{4}$ were shown to be approximately five to eight and two to six times higher than those of $\mathrm{GA}_{1}$ in the leaf sheaths and leaf blades, respectively. In Allium wakegi, $\mathrm{GA}_{1}, \mathrm{GA}_{3}, \mathrm{GA}_{4}, \mathrm{GA}_{12}, \mathrm{GA}_{15}, \mathrm{GA}_{19}$, and $\mathrm{GA}_{20}$ were identified as endogenous GAs in basal leaf sheaths, and the level of $\mathrm{GA}_{4}$ was relatively higher than that of $\mathrm{GA}_{1}+\mathrm{GA}_{3}$ (Yamazaki et al., 2002). These findings further confirm that in Alliaceae, including bunching onion, there are both 13-hydroxy and nonhydroxylation pathways of GA biosynthesis with the nonhydroxylation pathway to $\mathrm{GA}_{4}$ being predominant. Identification of $\mathrm{GA}_{3}$ suggests that the biosynthetic pathway to $\mathrm{GA}_{3}$ also exists in bunching onion. The biosynthetic pathway from $\mathrm{GA}_{20}$ to $\mathrm{GA}_{3}$ through $\mathrm{GA}_{5}$ has been reported in maize (Zea mays) (Fujioka et al., 1990) and other plant species (MacMillan, 1997) and from $\mathrm{GA}_{3}$ to $\mathrm{GA}_{95}$ in Prunus cerasus (Nakayama et al., 1996). GA 3 was also identified in $A$. wakegi (Yamazaki et al., 2002) but not in onion plants (Nojiri et al., 1993). Tashiro et al. (1995) reported that $A$. wakegi is a hybrid between bunching onion and shallot; thus, $\mathrm{GA}_{3}$ biosynthesis in this species could have originated from bunching onion.

GAs play an important role in bolting in other cold-requiring plants such as $R$. sativus (Nishijima et al., 1998), cabbage (Hamano et al., 2002), and tulip (Rebers et al., 1995). In the present study, expression of $A f G A 3$ ox 1 was observed during flower stalk growth. In addition, the level of AfGA3ox 1 transcript was higher during early-stage bolting in the stalk and was also detected during late-stage bolting (pollen and ovule formation stages) in the umbel. In Cucurbita maxima female flowers, higher levels of $\mathrm{GA}_{4}$ were identified along with increased expression of $C m G A 200 x 3$ and $C m G A 3 o x 3$ transcripts (Pimenta and Lange, 2006). Itoh et al. (2001) and Kobayashi et al. (1990) also reported that mature anthers of rice metabolize GAs with increased GA 3-oxidase mRNA expression during pollen differentiation in rice. Similarly, the findings presented here suggest that GAs also play important roles in pollen formation in bunching onion.

The putative Allium GA 3-oxidase gene was found on chromosome 7A of shallot by PCR-RFLP analysis using alien addition lines. It has also been reported that very high genome synteny exists in bunching onion and onion (Tsukazaki et al., 2008). Accordingly, the AfGA3oxl gene is also thought to be located on chromosome 7F in bunching onion. Shigyo et al. (1997) reported that the morphological characteristics of the FF + 7A line include "fast expansion of leaves" and "elongation of axillary buds from autumn to winter." We are therefore interested in determining the morphological changes related to the additional effects of the AfGA3oxl gene on chromosome 7A. Further studies are thus needed to clarify the relationship between the GA 3-oxidase gene and morphological changes using gene knockout in bunching onion and onion.

In conclusion, the regulation of the expression of GA 3-oxidase and endogenous GAs in bunching onion has been investigated. Bunching onion contains two biosynthetic sequences for GA synthesis, the early-13-hydroxylation and the non-hydroxylation pathways. Higher levels of non-13-hydroxylated GAs were observed in the leaf sheaths and leaf blades. When combined with higher responsiveness to $\mathrm{GA}_{4}$ in seedlings, the non-13-hydroxylation pathway is considered to be the predominant route of GA metabolism in bunching onion. A relative correlation between AfGA3ox 1 mRNA levels and $\mathrm{GA}_{4}$ content in the leaf was observed. AfGA3ox 1 was also involved in the regulation of stalk growth. Our results suggest that $A f G A 3 o x 1$ is a candidate responsible for the growth regulation in bunching onion.

\section{Literature Cited}

Chiang, H.H., I. Hwang, and H.M. Goodman. 1995. Isolation of the arabidopsis $\mathrm{GA}_{4}$ locus. Plant Cell 7:195-201.

Chiang, H.H., I. Hwang, and H.M. Goodman. 1997. Isolation of the arabidopsis $\mathrm{GA}_{4}$ locus. Plant Cell 9:979-980.

Davies, P.J. 2004. The plant hormones: Their nature, occurrence, and function, p. 1-15. In: Davies, P.J. (ed.). Plant hormones biosynthesis, signal transduction, action. Kluwer Academic Publishers, Dordrecht, The Netherlands.

Eguchi, T., Y. Ohika, and T. Matsumura. 1958. Studies on the seed production of welsh onion (Allium fistulosum L.). I. On the flower bud differentiation and development in welsh onion. Bul. Natl. Inst. Agr. Sci. E7:107-114 [in Japanese].

Fujioka, S., H. Yamane, C.R. Spray, B.O. Phinney, P. Gaskin, J. MacMillan, and N. Takahashi. 1990. Gibberellin $\mathrm{A}_{3}$ is biosynthesized from gibberellin $\mathrm{A}_{20}$ via gibberellin $\mathrm{A}_{5}$ in shoots of Zea mays $\mathrm{L}$. Plant Physiol. 94:127-131.

Gaskin, P. and J. MacMillan. 1991. GC-MS of the gibberellins and related compounds: Methodology and a library of spectra. Cantock's Enterprises, Bristol, UK.

Hamano, M., Y. Yamato, H. Yamazaki, and H. Miura. 2002. Endogenous gibberellins and their effects on flowering and stem elongation in cabbage (Brassica oleracea var.capitata). J. Hort. Sci. Biotechnol. 77:220-225.

Hedden, P. and Y. Kamiya. 1997. Gibberellin biosynthesis: Enzymes, genes and their regulation. Annu. Rev. Plant Physiol. Plant Mol. Biol. 48:431-460.

Hooley, R. 1994. Gibberellins: Perception, transduction and responses. Plant Mol. Biol. 26:1529-1555.

Inden, H. and T. Asahira. 1990. Japanese bunching onion (Allium fistulosum L.), p. 159-178. In: Rabinowitch, H.D. and J.L. Brewster (eds.). Onions and allied crops. Vol II. CRC Press, Boca Raton, FL. Ingram, T.J., J.B. Reid, I.C. Murfet, P. Gaskin, and C.L. Willis. 1984. Internode length in Pisum: The Le gene controls the 3 $\beta$-hydroxylation of gibberellin $\mathrm{A}_{20}$ to gibberellin $\mathrm{A}_{1}$. Planta 160:455-463.

Itoh, H., M. Ueguchi-Tanaka, N. Sentoku, H. Kitano, M. Matsuoka, and M. Kobayashi. 2001. Cloning and functional analysis of two gibberellin $3 \beta$-hydroxylase genes that are differently expressed during the growth of rice. Proc. Natl. Acad. Sci. USA 98:8909-8914.

Kobayashi, M., Y. Kamiya, A. Sakurai, H. Saka, and N. Takahashi. 1990. Metabolism of gibberellins in cell-free extracts of anthers from normal and dwarf rice. Plant Cell Physiol. 31:289-293.

Kobayashi, M., A. Sakurai, H. Saka, and N. Takahashi. 1989. Quantitative analysis of endogenous gibberellins in normal and dwarf cultivars of rice. Plant Cell Physiol. 30:963-969.

Kovats, E. 1958. Gas chromatographische charakterisierung organischer verbindungen, Teil 1: Retentions indices aliphatischer halogenide, alkohole, aldehyde and ketone. Helv. Chim. Acta 41:1915-1932 [in German].

Lester, D.R., J.J. Ross, P.J. Davies, and J.B. Reid. 1997. Mendel's stem length gene $(L e)$ encodes a gibberellin $3 \beta$-hydroxylase. Plant Cell 9:1435-1443.

MacMillan, J. 1997. Biosynthesis of the gibberellin plant hormones. Nat. Prod. Rep. 14:221-243.

Martin, D.N., W.M. Proebsting, and P. Hedden. 1997. Mendel's dwarfing gene: CDNAs from the Le alleles and function of the expressed proteins. Proc. Natl. Acad. Sci. USA 94:8907-8911.

Nakayama, M., T. Yokota, R. Sohma, L.N. Mander, B. Twitchin, H. Komatsu, H. Matsui, and M.J. Bukovac. 1996. Gibberellins in immature seed of Prunus cerasus: Structure determination and synthesis of gibberellin, GA $_{95}$ (1,2-didehydro-GA 20 ). Phytochemistry 42:913-920. Nishijima, T. and N. Katsura. 1989. A modified micro-drop bioassay using dwarf rice for detection of femtomol quantities of gibberellins. Plant Cell Physiol. 30:623-627. 
Nishijima, T., N. Katsura, M. Koshioka, H. Yamazaki, M. Nakayama, H. Yamane, I. Yamaguchi, T. Yokoya, N. Murofushi, N. Takahashi, M. Nonaka, and L.N. Mander. 1998. Role of endogenous gibberellins in cold-induced stem elongation and flowering of japanese radish (Raphanus sativus L.). J. Jpn. Soc. Hort. Sci. 67:319-324.

Nojiri, H., T. Toyomasu, H. Yamane, and N. Murofushi. 1993. Qualitative and quantitative analysis of endogenous gibberellins in onion plants and their effects on bulb development. Biosci. Biotechnol. Biochem. 57:2031-2035.

Pharis, R.P. and R.W. King. 1985. Gibberellins and reproductive development in seed plants. Annu. Rev. Plant Physiol. 36:517-568.

Pimenta, M.J. and T. Lange. 2006. Gibberellin biosynthesis and the regulation of plant development. Plant Biol. 8:281-290.

Rebers, M., E. Vermeer, E. Knegt, C.J. Shelton, and L.H.W. van der Plas. 1995. Gibberellin levels and cold-induced floral stalk elongation in tulip. Physiol. Plant. 94:687-691.

Shigyo, M., M. Iino, S. Isshiki, and Y. Tashiro. 1997. Morphological characteristics of a series of alien monosomic addition lines of japanese bunching onion (Allium fisutulosum L) with extra chromosomes from shallot (A. cepa L. Aggregatum group). Genes Genet. Syst. 72:181-186.

Shigyo, M., Y. Tashiro, S. Isshiki, and S. Miyazaki. 1996. Establishment of a series of alien monosomic addition lines of japanese bunching onion (Allium fisutulosum L) with extra chromosomes from shallot (A. cepa L. Aggregatum group). Genes Genet. Syst. 71:363-371.

Spielmeyer, W., M. Ellis, M. Robertson, S. Ali, J.R. Lenton, and P.M. Chandler. 2004. Isolation of gibberellin metabolic pathway genes from barley and comparative mapping in barley, wheat and rice. Theor. Appl. Genet. 109:847-855.

Swain, S.M. and N.E. Olszewski. 1996. Genetic analysis of gibberellin signal transduction. Plant Physiol. 112:11-17.

Talon, M., M. Koornneef, and J.A.D. Zeevaart. 1990. Endogenous gibberellins in Arabidopsis thaliana and possible steps blocked in the biosynthetic pathways of the semidwarf ga4 and ga5 mutants. Proc. Natl. Acad. Sci. USA 87:7983-7987.

Tashiro, Y., T. Oyama, Y. Iwamoto, R. Noda, and S. Miyazaki. 1995. Identification of maternal and paternal plants of Allium wakegi Araki by RFLP analysis of chloroplast DNA. J. Jpn. Soc. Hort. Sci. 63:819824.

Thomas, S.G., A.L. Philips, and P. Hedden. 1999. Molecular cloning and functional expression of gibberellin 2-oxidase, multifunctional enzymes involved in gibberellin deactivation. Proc. Natl. Acad. Sci. USA 96:4698-4703.

Tsukazaki, H., K. Yamashita, S. Yaguchi, S. Masuzaki, H. Fukuoka, J. Yonemaru, H. Kanamori, I. Kono, T.T.M. Hang, M. Shigyo, A. Kojima, and T. Wako. 2008. Construction of SSR-based chromosome map in bunching onion (Allium fistulosum). Theor. Appl. Genet. 117:1213-1223.

Wan, C. and T.A. Wilkins. 1994. A modified hot borate method significantly enhances the yield of high-quality RNA from cotton (Gossypium hiirsutum L.). Anal. Biochem. 233:7-12.

Xu, X.L., D.A. Gage, and J.A.D. Zeevaart. 1997. Gibberellins and stem growth in Arabidopsis thaliana. Plant Physiol. 114:1471-1476.

Yamaguchi, S. 2008. Gibberellin metabolism and its regulation. Annu. Rev. Plant Physiol. 59:225-251.

Yamaguchi, S., M.W. Smith, R.S. Brown, Y. Kamiya, and T.P. Sunday. 1998. Phytochrome regulation and differential expression of gibberellin 3 $\beta$-hydroxylase genes germinating Arabidopsis seeds. Plant Cell 10:2115-2126.

Yamasaki, A., H. Miura, and K. Tanaka. 2000a. Effect of photoperiods before, during and after vernalization on flower initiation and development and its varietal difference in japanese bunching onion (Allium fistulosum L.). J. Hort. Sci. Biotechnol. 75:645-650.

Yamasaki, A., K. Tanaka, M. Yoshida, and H. Miura. 2000b. Effects of day and night temperatures on flower-bud formation and bolting of japanese bunching onion (Allium fistulosum L.). J. Jpn. Soc. Hort. Sci. 69:40-46.

Yamazaki, H., T. Nishijima, M. Koshioka, and H. Miura. 2002. Gibberellins do not act against abscisic acid in the regulation of bulb dormancy of Allium wakegi Araki. Plant Growth Regulat. 36:223-229. Zeevaart, J.A.D., D.A. Gage, and M. Talon. 1993. Gibberellin $A_{1}$ is required for stem elongation in spinach. Proc. Natl. Acad. Sci. USA 90:7401-7405. 